\title{
DECOLONISING THE AFRICAN UNIVERSITY AGAIN
}

\author{
Y. Waghid \\ Department of Education Policy Studies \\ Stellenbosch University \\ Stellenbosch, South Africa \\ https://orcid.org/0000-0003-2565-824X
}

\section{ABSTRACT}

The notion of the African university ought to be decolonised on the grounds that decolonisation enhances humanisation and rehumanisation, as well as cosmopolitan pluriversalism. This article argues that unless the university takes its task to liberate, resist, and advance cosmopolitan ideals seriously, the decolonisation of the African university will remain elusive.

Keywords: African university, (re)humanisation, decolonisation

\section{WHY SHOULD THE FOCUS ON HIGHER EDUCATION IN (SOUTH) AFRICA REMAIN ON DECOLONISATION?}

Every end-of-year, I receive a list of prospective postgraduate students wishing to pursue either a Master's or doctoral degree in our department. Often when I inquire from students on the list as to why they have chosen our university to study towards, say, a PhD qualification, they offer varying responses ranging from the university's world-class status to their interest in acquiring a marketable qualification that would provide a springboard for their participation in a competitive global market economy. If an African university were to be conceived only in its economic, commodified and monetised viabilities, then it is worthwhile to reconsider why such a university ought to be decolonised. If students consider an advanced university degree only for upward social mobility, competition, and participation in a global market economy, then there is something drastically wrong with the thinking of such students. Alternatively, if the university in Africa continues to organise and market its higher education purposes around competition, rankings, and the commodification of knowledge, then such a university ought to be decolonised as the focus on higher education, especially in Africa, cannot persistently be on markets and meritocracy. In this article, I revisit at least three theoretical ideas about why the university in Africa should be decolonised again.

\section{ON THREE GENRES OF DECOLONISATION OF HIGHER EDUCATION}

Firstly, Franz Fanon's (1963) argument against the exclusion of others (foreigners) remains 
constitutive of decolonisation. For Fanon, racial hatred, exploitation, and genocide advance human exclusion and dehumanisation $(1963,254)$. Moreover, if one can subvert all forms of domination, one would have taken care of exclusion. It does seem as if some students in Africa remain subjected to the idea that the university remains their pathway to upward mobility and a better material future. Maybe their futures might become materially enhanced, but this does not mean they would have been liberated. They might have gained a better position in the social hierarchy or an improved position within a profession, but this does not mean that their humanity became more inclined towards subverting racial hatred, the exploitation of others, and ongoing acts of genocide against marginalised humans in many parts of the African continent. The point is, these students might not have been rehumanised and hence, seem to remain colonised. The decolonisation of minds implies that students should become liberated from all forms of human exclusion, particularly offering resistance against that which misconstrues and subverts the quest for human liberation.

Nowadays, the decolonisation of the African university has become a necessary practice to oppose the escalating levels of crime against humanity and the increasing levels of human suffering and trauma in many parts of the continent. If the African university cannot contribute to quelling the unabated human rights violations on the continent, then such a university has not been decolonised. The political and societal crises would only deepen due to such a higher education institution's educational predicament.

Secondly, in contrast to Ngugi Wa Thiong'o's (1979) argument in defence of a decolonised African university about turning inwards towards the self - a matter of recentering the self - Waghid, Waghid and Waghid (2018) offer an argument towards decentering the self. By decentering the self, university scholars should look at what is important for others rather than autonomous selves concerning language, culture, art, dance, religion, history, geography, literature, and education. In other words, to decentre university practices according to the aspirations of others would be more rehumanising, liberatory, and disruptive (Waghid et al. 2018). Here, I specifically think about many universities on the continent that consider their academics as human capital constantly having to remain subjected to rankings, ratings, and market metrics. For example, one does not matter or count at universities in (South) Africa if unrated or if one does not have a favourable or expected rating or a huge external grant that provides funding for a relevant research project. The point is, rewards and incentives seem to centre around institutional autonomy - what the institutional self demands - often at the expense of other-selves.

Moreover, often institutional autonomy is subjected to economic principles and market imperatives. Sometimes the other-selves invariably provide the backbone to the university's 
teaching-learning programme that does not always receive the same privileges as its research imperative. Implicitly, the marketised university has largely contributed to the schism between teaching-learning and research, and hence, the decolonised university of teaching-learningresearch remains in waiting. Of course, my potential critic might question why community engagement does not constitute the work of other-selves? If the academic work of other-selves is not guided towards the knowledge interests of communities, then such work has not been decolonised. This implies that within teaching-learning-research, the engagement with the community is never absent. Teaching-learning-research that does not focus on an external community is a spuriously colonised practice with no pedagogical place in higher education on the continent.

Thirdly, Achille Mbembe's (2016) notion of cosmopolitan pluriversalism seems apt in cultivating the idea of a genuinely decolonised African university. For Mbembe $(2016,37)$,

" $[\mathrm{t}] \mathrm{o}$ decolonize the university is to ... reform it with the aim of creating a ... more open critical cosmopolitan pluriversalim - a task that involves a radical refounding of our ways of thinking and a transcendence of our disciplinary divisions."

What attracts me to Mbembe's (2016) idea of a decolonised (African) university are the notions of openness, criticality, and cosmopolitanism. An open university allows pedagogical spaces for deliberation, agreement, and dissonance. Of course, one cannot deny that the university in the postcolonial era has suppressed legitimate critical voices and the aspirations of the previously marginalised. The post-apartheid South African university is a typical example of how democratic practices, cultures, and imaginaries have manifested. Yet, the practice of dissonance as sudden upheavals of thought that could rupture the taken-for-granted - an idea I borrowed from Jacques Derrida (2004) - has not always been ubiquitously exercised in the university (Waghid et al. 2021).

One specific example which comes to mind involves the recent reliance of the university on what has been coined emergency remote teaching (ERT). Online ERT curriculum packages seemed to have emerged to deal with the ongoing absence of students from university campuses during this time of the coronavirus pandemic. Yet, what seems to dominate the course content of many ERT materials is a form of teaching that actually excludes learning - more specifically, teaching-learning seems to be presented without allowing for dissensus with students being coerced into content that does not seem to advance critique. If a decolonised African university were to be concerned with open and critical thought, how come ERT seems to undermine what provocative and evocative teaching-learning pedagogical action ought to entail?

Finally, a university that does not advance cosmopolitan ideals would remain closed to 
issues of diversity, autonomy, and the necessary practice of transformation. How is it possible for a university to contend with differences, dissensus, and imagination if it fails to advocate what it means to be other, different, and heterogeneous? A university that does not disrupt its institutional culture of compliance continues to treat its students only as recipients of information. Moreover, to remain loyal to homogenous practices of the global North would not have done much to pursue the decolonisation of higher education projects on the continent (Waghid et al. 2020). The time is now to decolonise the African university again and again.

\section{REFERENCES}

Derrida, J. 2004. Eyes of the university: Right to philosophy 2. (Translated by J. Plug and Others). Stanford: Stanford University Press.

Fanon, F. 1963. The wretched of the earth. London: Penguin Books.

Mbembe, A. J. 2016. "Decolonizing the university - New directions." Arts \& Humanities in Higher Education 15(1): 29-45. https://doi.org/10.1177/1474022215618513.

Wa Thiong'o, N. 1979. Decolonising the mind: The politics of language in African literature. Oxford: James Currey.

Waghid, Y., F. Waghid, and Y. Waghid. 2018. Rupturing African philosophy on teaching and learning: Ubuntu justice and education. London \& New York: Palgrave-MacMillan.

Waghid, Y., C. H. Manthalu, J. Terblanche, F. Waghid, and Y. Waghid. 2020. Cosmopolitan education and inclusion: Human engagement and the self. London \& New York: Palgrave-MacMillan.

Waghid, Y., F. Waghid, J. Terblanche, and Z. Waghid. 2021. Higher teaching and learning for alternative futures: A renewed focus on critical praxis. London \& New York: PalgraveMacMillan. 